\title{
THRESHOLD OF REAL EXCHANGE RATE AND THE PERFORMANCE OF MANUFACTURING INDUSTRY IN INDONESIA
}

\author{
Ndari Surjaningsih ${ }^{1}$ \\ Novi Maryaningsih \\ Myrnawati Savitri
}

\begin{abstract}
This paper analyzes the presence of the threshold of the real rupiah exchange rate which influences the profitability of manufacturing industry in Indonesia. By using a non-dynamics panel data over medium and large scale companies during 2001-2009, we found the threshold of 82.4 for the real rupiah exchange rate (REER). The REER index ranging from 82.24 to 101.13 with the change value between $-5.01 \%$ and $20.09 \%$ (yoy) is secure for the profitability of Indonesian manufacturing industry. This paper also conform the significant affect of Total Factor Productivity on firm's profitability.
\end{abstract}

Keywords: Profitability, Manufacturing industry, exchange rate JEL Classification: F1, D21, L6

1 Researcher on Economic Research Group, Department of Ecomomic Research and Monetary Policy, Bank Indonesia. The views on this paper is solely of the authors and not necessarily reflect the views of Bank Indonesia. 


\section{INTRODUCTION}

The manufacturing industry in Indonesia play strategic role with its large contribution on Gross Domestic Product, high labor absorption, significant export contribution, and high forward and backward lingkage to other sectors, (Surjaningsih and Permono, 2014). On the other hand, the Rupiah's rate is an important macroeconomic indicator, where a change of Rupiah's rate will affect domestic inflation and the output. The exchange rate directly affect inflation through the cost of import (pass-through effect), while its impact on output work through the international trade activities.

The depreciation of the exchange rate will give a positive impact towards the export of a country because the cost of the goods exported will be cheaper if converted in the importer money currency.

Meanwhile, studies about the impact of the exchange rate towards the micro level, especially towards the works of manufacturing industry, is still relatively limited. One of the studies discussed this issue was conducted by Surjaningsih, et. al. (2011) which found a positive impact on real Rupiah exchange rate toward the performanced of the manufacturing industry. The appreciation of real Rupiah exchange rate gave a positive impact on the profitability of the sub-sector of manufacturing industry. This finding related to the production characteristic in the sub-sector of the manufacturing industry which still needed import raw material. However, that positive influence would decrease as the rapid growth of export activities compared to the import activities. The analysis of Yanuarti (2006) used the table of Input-Output which concluded a conclusion that in line with that study, in which the appreciation of the exchange rate caused the increased of the output of the manufacturing industry. It was just that one of the weaknesses of using the I-O table was the used model had not yet to calculate the possibility of the decline of demand of the output industry which came from the export as the result of the drop off of the competitiveness.

In the current global condition, the potency of the appreciation of the exchange rate in emerging countries, including Indonesia, is appreciable. That potency comes up because of the global excess liquidity and two-speed recovery occur in the growth of world economy which cause many capital flow to the group of emerging countries. The fundamental condition and the level of return from the emerging countries group which are relatively stronger than that of the developed countries become the push factor for the entry of capital flow to the group of emerging countries. By considering that external condition, a study on the threshold of the appreciation of Rupiah exchange rate which still supports the performance of manufacturing industries is needed.

2 Dampak Apresiasi Nilai Tukar terhadap Kinerja Industri Pengolahan, Tri Yanuarti (2006), Catatan Riset. 
The objective of this research is to find out the threshold of the real Rupiah exchange rate, either in the term of level or growth, which influences negatively toward the performance of manufacturing industry. The expected benefit is the availability of information about level and the change of the real Rupiah exchange rate which give pressure to the performance of manufacturing industry.

\section{THEORY}

In economic theory, a producer is assumed to behave rationally, which is by trying to maximize the profit. In order to gain that purpose, the producer is faced by two decisions, which are about the number of the output that must be produced, and, how many as well as how the combination of the production factor will be used. The decision that must be chosen by a producer is based on the assumption that producer operates in an elastic market. In an elastic market, the cost of input and output face by the producer has no ability to influence the market. In contrary, the cost of input and output is determined by the market, so that the producer has no capacity to control the market. On the other hand, in the in elastic market and monopoly market, the producer can determine the cost of the output, in a view of that, the producer will face one more decision, which is about the sale cost of the output which is charged to the consumer.

The research which sees the influence of the exchange rate movement toward the performance of the company, especially in the manufacturing sector is relatively limited. Among few of study/ research on this topic, Fung conducted a research with a case study in a company in Canada by inserting the elements of exchange rate into Krugmans' theory about monopolistic competition. Fung (2007) examined the influenced of the exchange rate toward the extensive and intensive margin of the company and concluded thata there was a negative impact on the appreciation of the exchange rate toward the extensive margin. That negative impact caused a decerase on the probability of survival and entry rate of a company to an industry. The explanation of that conclusion was that the appreciation of domestic exchange rate gave cost advantage to the foreign company and forced the low productivity domestic company to go out of the industry. On the other hand, the effect of the appreciation of the exchange rate toward the domestic company which classified as intensive margin was the decrease of the sale of the company. In the case of a high exit rate, the appreciation of the exchange rate gave a positive impact toward the sale and vice versa.

In that research, Fun assumed that labor was the only production factor. The appreciation of domestic exchange rate would benefit for the company outside the country because its production cost was cheaper if it was counted in domestic currency, and, on the other side, it improved the competition of domestic company both in domestic and export market. In order to survive in a rapid competition, the domestic company must decline its mark-up pricing, so 
that the domestic company would not work in the economic scale that would be out of the market scale.

Besides Fung, Baggs (2007) did a similar research but inserted the heterogenity productivity of company in which this was assumed as homogenic in Fung's research. This completion combined Fung model with the model of international commerce and company heterogenity by Melitz (2003) and Mellitz and Ottviano (2005). Baggs concluded that the increased of competition because the world trade forced the low productivity company to walk out the market and gave more benefit for the more productive company to develop its expansion of market share. In other words, the inclined of the competition because of the appreciation of domestic exchange rate caused the domestic company to lessen its mark up pricing so that it could survive in the market. However, for the less-productive-company, it was impossible for this company to decline the mark up, so that this type of company should exit from the market. In contrast, the depreciation of domestic exchange rate would benefit the domestic company because it leveled up this company's competitive position in the international market, and so this would attract the entry of new company into the market and would decrease the failure possibility of the domestic company, including the company with less productivity.

In 2011, Baggs et.al conducted other research on the relation of exchange rate with the condition of the company. ${ }^{3}$ This research found out the impact of the real Canadian exchange rate toward the size of the company, profit level and sompany's survival in Canada. The appreciation of the real Canadian exchange rate impacted negatively toward the intensive margin, it was measured by the sale level and employment, and toward profit. In a short term, the exchange rate movement caused the companies in Canada to absorb the causing impact rather than they should change the size of their companies. To see the impact, Baggs used the following equation:

$$
\ln \operatorname{Profit}_{f t}=\alpha+\left(\pi_{1}+\pi_{2} \ln d_{f t}\right) \ln E R_{i t}+\gamma x_{f t-1}+\delta y_{i t-1}+\varepsilon_{f t}
$$

In which In Profit ${ }_{\mathrm{ft}}=$ logarithm of company profit; $\mathrm{d}_{\mathrm{ft}}=$ the distance location of the company with the border line of Canada-US; $E R_{i t}=$ industry-specific real Canada-US bilateral exchange rate; $\mathrm{x}_{\mathrm{ft}-1}=$ vector of lagged firm-level controls, such as the age of the company , leverage and size of the company; $y_{i t}=$ control variable for industry and aggregate of macro economy, such as the growth of industry sale, the level of industry concentration, and GDP of Canada.

For the case in Indonesia, Surjaningsih, et.al (2011) studied the impact pf Rupiah exchange rate toward the performance of Indonesia manufacturing industry. That research used statistic data of big and medium industry year 2000-2007 with method of unbalanced panel static

3 Baggs, J. Et.al. (2011), "Exchange Rate Movements and Firm Dynamics in Canadian Retaillndustries" 
fixed effect ${ }^{4}$. From the testing, it stated that factors influenced the performance of the industry sector that was proxied by a level of profit were productivity, the movement of real exchange rate, and the level of interest rate. Whereas the ratios of concentration and market potency (proxied by the growth of sale), though giving signs based on expectation, they did not give an empiric evidence to influence the performance of industry sector

Therefore, the appreciation of the real Rupiah exchange rate occurred along period of 2000-2007 had yet to give pressure to the performance of industry sector in Indonesia aggregately, except for a few industry sectors with export orientation. This pressure if the real Rupiah exchange rate had yet to turn up because it related with the characteristic of industry that were oriented more into domestic market rather than into export market and also due to the needs of raw material and helping import. The needs of raw material and import help in some sub-sectors of industry caused the company to get the benefit from the appreciation of exchange rate in the form of cheaper imported raw material price. Thus, it was indicated that the amount of manufacturing industry profit level could be influenced by the high and low change of the real exchange rate, in which in a certain level or level of change (threshold) of the real Rupiah exchange rate would give pressure toward the performance of manufacturing industry sector. That impact was assumed based on the orientation on sub-sector of industry which oriented on export and import.

\section{METHODOLOGY}

\subsection{Threshold Regression}

The regression threshold method is developed for a non-dynamic panel with an individual specific fixed effect. The development of this method is to answer the question whether the regression function is identical for the entire observation in a sampling or this observation is actually has its own characteristic based on its class.

$$
y_{i t}=\mu_{i}+\beta_{1}^{\prime} x_{i t} I\left(q_{i t} \leq \gamma\right)+\beta_{2}^{\prime} x_{i t} I\left(q_{i t}>\gamma\right)+e_{i t}
$$

The regression threshold method that will be implemented is that used by Hansen (1999) for non-dynamic panel data. The data used is balanced panel with the structure $\left\{y_{i t^{\prime}} q_{i t^{\prime}} x_{i t}: 1\right.$ $\leq \mathrm{i} \leq \mathrm{n}, 1 \leq \mathrm{t} \leq \mathrm{T}$ \}. Dependent variable is shown by $y_{i t}$ for individual $i$ and time $t$ which is scalar and $x_{i t}$ is an independent variable which is matrix, while $q_{i t}$ is variable threshold in the form of scalar and $\mu_{i}$ shows individual effect. Therefore, the regression threshold method for panel data can be symbolized as follow:

4 Robustness test yang dilakukan : uji Allerano-Bond, Sargan Test untuk menentukan model panel dinamis atau statis, serta Hausman Test untuk menentukan random effect atau fixed effect. 


$$
y_{i t}=\mu_{i}+\beta_{1}^{\prime} x_{i t} I\left(q_{i t} \leq \gamma\right)+\beta_{2}^{\prime} x_{i t} I\left(q_{i t}>\gamma\right)+e_{i t}
$$

Where I..) is an indicator function which is valued 1 or 0 depend on its threshold value.

$$
\begin{aligned}
& I\left(q_{i t} \leq \gamma\right)\left\{\begin{array}{l}
1 \mathrm{jika}_{i t} \leq \gamma \\
0 \mathrm{jika} q_{i t}>\gamma
\end{array}\right. \\
& I\left(q_{i t}>\gamma\right)\left\{\begin{array}{l}
1 \mathrm{jika} q_{i t}>\gamma \\
0 \mathrm{jika} q_{i t} \leq \gamma
\end{array}\right.
\end{aligned}
$$

So that equation (1) can be written:

$$
y_{i t} \begin{cases}\mu_{i}+\beta_{1}^{\prime} x_{i t}+e_{i t}, & q_{i t} \leq \gamma \\ \mu_{i}+\beta_{2}^{\prime} x_{i t}+e_{i t} & q_{i t}>\gamma\end{cases}
$$

Or also can be written as follow:

$$
x_{i t}\left\{\begin{array}{l}
x_{i t} I\left(q_{i t} \leq \gamma\right) \\
x_{i t} I\left(q_{i t}>\gamma\right)
\end{array}\right.
$$

And $\beta=\left(\beta_{1}^{\prime}{ }_{1}^{\prime}{ }_{2}\right)$ so that equation (1) in above will equall to

$$
y_{i t}=\mu_{i}+\beta^{\prime} x_{i t}(\gamma)+e_{i t}
$$

In model (1), sample is grouped into two parts depend on whether those data is located in above or below $\gamma$ threshold. Both of these data groups (regimes) are categorized by the regression slope of $\beta_{1}$ and $\beta_{2}$. The first group, which is called first regime, contain sample that fulfill $q_{i t} \leq$ $\gamma$ criteria and in the second group is called second regime that contains sample which fulfill $q_{i t}$ $>\gamma$ criteria. If $\beta_{1} \neq \beta_{2}$ then it is said that there is threshold in regression equation and model (1) is feasible to be used, but if $\beta_{1}=\beta_{2}$ then the ordinary regression model must be used.

For that reason, it is needed to test the hypothesis that $\beta_{1}=\beta_{2}$. The result of this test will determine whether the (1) threshold regression model or the ordinary regression model that will be used. In this threshold model, it assumed that $x_{i t}$ and $q_{i t}$ are not varied toward time or in other word model used is static fixed effect panel. The error of $e_{i t}$ is assumed as independent and identically distributed (i.i.d) with mean 0 (zero) and variance $\sigma^{2}$ or $e_{i t} \sim$ i.i.d $N\left(0, \sigma^{2}\right)$. 
Equation (1) if the mean is taken, it will result

$$
\bar{y}_{i}=\mu_{i}+\beta^{\prime} \bar{x}_{i}(\gamma)+\overline{e_{i}}
$$

With

$$
\begin{gathered}
\bar{y}_{i}=\frac{1}{T} \sigma_{t=1}^{T} y_{i t}, \bar{e}_{i}=\frac{1}{T} \sigma_{t=1}^{T} e_{i t, \text { and }} \\
\bar{x}_{i}(\gamma)=\frac{1}{T} \sum_{t=1}^{T} x_{i t}(\gamma) \\
\bar{x}_{i} \gamma=\left\{\begin{array}{l}
\frac{1}{T} \sum_{t=1}^{T} x_{i t} I\left(q_{i t} \leq \gamma\right) \\
\frac{1}{T} \sum_{t=1}^{T} x_{i t} I\left(q_{i t}>\gamma\right)
\end{array}\right.
\end{gathered}
$$

The difference between equation (2) and (3) results

$$
y_{i t}-\bar{y}_{i t}=\left[x_{i t} \gamma-\bar{x}_{i t}(\gamma)\right] \beta^{\prime}+\left[e_{i t}-\bar{e}_{i t}\right]
$$

Or it can be written

$$
y_{i t}^{*}=\beta^{\prime} x_{i t}^{*}(\gamma)+e_{i t}^{*}
$$

If the data and individual error are placed in vector with one time period erased, it becomes:

$$
y_{i}^{*}=\left[\begin{array}{c}
y_{i 2}^{*} \\
\vdots \\
y_{i T}^{*}
\end{array}\right], \quad x_{i}^{*}(\gamma)=\left[\begin{array}{c}
x_{i 2}^{*}(\gamma) \\
\vdots \\
x_{i T}^{*}(\gamma)
\end{array}\right], e_{i}^{*}=\left[\begin{array}{c}
e_{i 2}^{*} \\
\vdots \\
e_{i T}^{*}
\end{array}\right]
$$

$Y^{*}, X^{*}(\gamma)$ and $e^{*}$ are individual data notation that is stacked then 


$$
Y^{*}=\left[\begin{array}{c}
y_{1}^{*} \\
\vdots \\
y_{n}^{*}
\end{array}\right], \quad X^{*}(\gamma)=\left[\begin{array}{c}
x_{1}^{*}(\gamma) \\
\vdots \\
x_{n}^{*}(\gamma)
\end{array}\right], e^{*}=\left[\begin{array}{c}
e_{1}^{*} \\
\vdots \\
e_{n}^{*}
\end{array}\right]
$$

So that the equation (4) can be written

$$
Y=X^{*}(\gamma) \beta+e^{*}
$$

For the $\gamma$ value, coefficient or $\beta$ slope can be estimated with Ordinary Least Square (OLS) method and it will give the same result with equation:

$$
\widehat{\beta}(\gamma)=\left(X^{*}(\gamma)^{\prime} X^{*}(\gamma)\right)^{-1} X^{*}(\gamma)^{\prime} Y^{*}
$$

With residual regression

$$
\hat{e}^{*}(\gamma)=Y^{*}-X^{*}(\gamma) \beta(\gamma)
$$

And the sum of square error

$$
\begin{aligned}
& S_{1}(\gamma)=\hat{e}^{*}(\gamma)^{\prime} e^{*}(\gamma) \\
& =Y^{* \prime}\left(I-X^{*}(\gamma)^{\prime}\left(X^{*}(\gamma)^{\prime} X^{*}(\gamma)\right)^{-1} X^{*}(\gamma)^{\prime}\right) Y^{*}
\end{aligned}
$$

The $\gamma$ estimation is conducted by minimazing the sum of square error in above equation:

$$
\hat{\gamma}=\operatorname{argmin} S_{1}(\gamma)
$$

With the bottom limit and up limit toward threshold:

$$
\Gamma=(\underline{\gamma}, \bar{\gamma})
$$

The calculation of value estimation of $\gamma$ threshold is conducted by finding the smallest of $\mathrm{S}_{1}(\gamma)$ value where the most value variation is as many as $\mathrm{nT}$ units. For doing minimization, the observation value is ordered continuously then the smallest percentile value is erased, $\eta \%$, and the biggest percentile value is erased, $(1-\eta) \%$, for $\eta>0$. The residual observation value from the previous calculation as many as $\mathrm{N}$ observations is $\gamma$ value which isas $\hat{\gamma}$ candidate. This research will use simplification method as in Hansen (1999) by finding $\hat{\gamma}$ candidate in certain quantile, which are $\{1,00 \% ; 1,25 \% ; 1,50 \% ; 1,75 \%$; $.98,50 \% ; 98,75 \% ; 99,00 \%\}$ consisted from 400 quantiles. 
The regime distribution or $\gamma$ determination considers the number of samples in every regime where the number of samples in one of the regimes can not be too low. Thus, it needs to be sured that the minimum of sample percentage is located in the both of these different regimes for instance $1 \%$ or $5 \%$ of total samples. If $\hat{\gamma}$ is already gathered then the estimation of $\beta$ value is the modification from (6):

$$
\hat{\beta}=\hat{\beta}(\hat{\gamma})
$$

With residual vector

$$
\hat{e}^{*}=\hat{e}^{*}(\hat{\gamma})
$$

And residual variation

$$
\hat{\sigma}^{2}=\frac{1}{\mathrm{n}(\mathrm{T}-1)} \hat{\mathrm{e}}^{*^{\prime}} \hat{\mathrm{e}}^{*}=\frac{1}{\mathrm{n}(\mathrm{T}-1)} S_{1}(\gamma)
$$

\section{Significancy of the Threshold}

After getting the threshold value, it is needed to conduct a test whether the influence of this threshold is significant or not with hypothesis as follows:

$$
\begin{aligned}
& H_{0}: \beta_{1}=\beta_{2} \\
& H_{1}: \beta_{1} \neq \beta_{2}
\end{aligned}
$$

The assumption used in this $\mathrm{H}_{0}$ test is that the value of $\gamma$ threshold can not be identified because there is no threshold influence so that the test of its likelihood ratio has no standard distribution. The critical value determination of this model is conducted by bootstrap procedure as shown in Hansen (1996) which aimed to simulate the asymptotic distribution from likelihood ratio test.

Below there is no threshold in $\mathrm{H}_{0}$; model (2) can be rewrittenas

$$
y_{i t}=\mu_{i}+\beta^{\prime} x_{i t}+e_{i t}
$$

And after passing the process of fixed effect transformation, equation (4) becomes

$$
y_{i t}^{*}=\beta^{\prime} x_{i t}^{*}+e_{i t}^{*}
$$

$\beta_{1}$ parameter is estimated by using least square method then resulting $\widetilde{\beta}_{1}$ with residual $\tilde{e}_{i t}^{*}$ and sum of square errors $S_{0}=\widetilde{e}^{*^{\prime}} \widetilde{e}^{*}$. Thereby that likelihood ratio test for $\mathrm{H}_{0}$ can be calculated based on (12). 


$$
F_{1}=\frac{S_{0}-S_{1}(\hat{\gamma})}{\hat{\sigma}^{2}}
$$

$F_{1}$ distribution in the previous explanation is not a standard distribution dominated by $\chi_{k}{ }^{2}$ distribution so the critical value can not be known. The critical value determination from $\mathrm{F}$ test is conducted by estimating from $\mathrm{F}$ asimptotic distribution through bootstrap procedure. The steps in bootstrap procedure are as follow:

1. Treat the independent variable $x_{i t}$ and threshold variable $q_{i t}$ as given and use the constant value of $x_{i t}$ and $q_{i t}$ when conducting bootstrap procedure.

2. Take the residual $\hat{e}_{i t}^{*}$ and conduct a grouping based on individual:

$$
\hat{e}_{i}^{*}=\left(\hat{e}_{i 1}^{*}, \hat{e}_{i 2}^{*}, \ldots \ldots, \hat{e}_{i T}^{*}\right)
$$

3. Use sample distribution $\left\{\hat{e}_{1}^{*}, \hat{e}_{2}^{*}, \ldots ., \hat{e}_{n}^{*}\right\}$ as the empirical distribution for used in bootstrap time.

4. Take random sample (with returning) from empirical distribution on number 3 above and use its error to take bootstrap sample below $H_{0}$.

5. With this bootstrap sample, estimate models, which are below $H_{0}$ in equation (12) and $H_{1}$ in equation (4), and calculate the $F_{1}$ likelihood ratio according to equation (13).

6. Repeat the steps from number 1 to 5 in many times such as 1.000 times.

7. This bootstrap procedure will result p-value that is asimptotik for $F_{1}$ below $H_{0}$.

8. $H_{0}$ is rejected if the $p$-value of bootstrap is bigger than the expected critical value.

\section{Consistency of the Threshold}

After the test of threshold significancy above and proven that the effect of threshold is exist in model $\left(\beta_{1} \neq \beta_{2}\right)$, then the next step is conducting a test whether $\hat{\gamma}$ is a consistent estimator for $\gamma_{0}$ (the actual value of $\gamma$ ) or not. $\hat{\gamma}$ is called as a consistent estimator for $\gamma_{0}$ if fulfilling 2 (two) requirements, first, the likelihood ratio $\gamma_{0}$ is lower than its critical value, and we use the following null hyphotesis:

$$
\begin{aligned}
& H_{0}: \gamma=\gamma_{0} \\
& H_{1}: \gamma \neq \gamma_{0}
\end{aligned}
$$


With likelihood ratio

$$
L R_{1}(\gamma)=\frac{S_{1}(\gamma)-S_{1}(\hat{\gamma})}{\hat{\sigma}^{2}}
$$

$H_{0}$ is rejected if the value of $L R_{1}\left(\gamma_{0}\right)$ is bigger than its critical value.

For conducting this calculation, used some technical assumptions: if $\gamma_{0}$ is the actual value of $\gamma, \theta=\beta_{2}-\beta_{1}$ and $C=n^{\alpha} \theta$, where $\alpha C(0,1 / 2)$. If $f_{t}(\gamma)$ is density function from $q_{i t}$ and $z_{\text {it }}$ $=C^{\prime} x_{i t}$, then

$$
D(\gamma)=\sum_{t=1}^{T} E\left(z_{i t}^{2} \mid q_{i t}=\gamma\right) f_{t}(\gamma)
$$

And $D=D\left(\gamma_{0}\right)$. Conditional density from $q_{i k}$ given $q_{i t}$ is symbolized with $f_{k \mid t}\left(\gamma_{1} \mid \gamma_{2}\right)$. Some assumptions used are:

1. For every t, $\left(q_{i t^{\prime}} x_{i t^{\prime}} e_{i t}\right)$ independent and identically distributed (i.i.d) acrossi;

2. For every i, $e_{i t}$ i.i.d overt and independent toward $\left\{\left(x_{i j}, q_{i j}\right)_{j=1}^{T}\right\}$ and $E\left(e_{i t}\right)=0$;

3. For every $\mathrm{j}=1, \ldots, \mathrm{k}, P\left(x_{i 1}^{j}=x_{i 2}^{j}=\cdots=x_{i T}^{j}\right)<1$, where $x_{i t}^{j}$ is element at-j from $x_{i t^{\prime}}$.

4. For $s>2, E\left|X_{i t}\right|^{s}<\infty$ and $E\left|e_{i t}\right|^{s}<\infty$;

5. For $C<\infty$ and $0<\alpha<1 / 2, \theta=\mathrm{n}^{-\alpha} \mathrm{C}$;

6. $D(\gamma)$ continue at $\gamma=\gamma_{0}$

7. $0<\mathrm{D}<\infty$;

8. For $k>t, f_{k \mid t}\left(\gamma_{0} \mid \gamma_{0}\right)<\infty$.

Under the assumptions from 1 to 8 above and $H_{0}: \gamma=\gamma_{0}$

$$
L R_{1}(\gamma) \rightarrow d \xi
$$

When $\mathrm{n} \rightarrow \infty$, where $\xi$ is random variable with distribution function

$$
P(\xi \leq x)=(1-\exp (-x / 2))^{2}
$$

The equation (15) above shows that likelihood ratios are not standard distribution but they are free from disturbance parameter. Moreover, another assumption which is used is $\left(\beta_{2}\right.$ $\left.-\beta_{1}\right) \rightarrow 0$, if $n \rightarrow \infty$, it means that the slope difference is in between two small regime toward the number of sample. It can be concluded that equation (15) will give a better result in a smaller 
value of $\left(\beta_{2}-\beta_{1}\right)$. Nevertherless, if the threshold effect in model is big, then the estimation of this threshold is quite accurate.

The distribution function (16) above has an inverse form that is easier to calculate the critical value:

$$
c(\alpha)=-2 \log (1-\sqrt{1-\alpha})
$$

$H_{0}$ will be rejected in $\alpha$ asimptotik level, if $L R_{1}\left(\gamma_{0}\right)$ is more than the value of $c(\alpha)$.

The second requirement for the threshold to be valid is the value of $\hat{\gamma}$ is located in the range confidence interval. According to Hansen (1997), the best procedure to arrange the confidence interval for $\gamma$ was by creating "no-rejection region" using $\gamma$ likelihood ratio statistic. In order to create an asimptotik confidence interval $(\mathrm{Cl})$ for $\gamma$, the confidence level of $1-\alpha$ from "no-rejection region" was a group of $\gamma$ values where $\mathrm{LR}_{1}(\gamma) \leq c(\alpha)$. This $\mathrm{Cl}$ was an output from the calculation of model estimation. To get the least square estimation $\hat{\gamma}$, it was conducted by ordering calculation the sum of square error $S_{1}(\gamma)$ in equation (3.17). The sequence of likelihood ratio $\operatorname{LR}_{1}(\gamma)$ is re-normalization from the previous calculation number so there is no need to do further calculation.

\subsection{Data and Empirical Model}

In this research, the model which was used was based on the model used by Baggs (2011), which measured the impact of the real exchange rate toward the profitability of a company. The equation inserted the control variable for industry which were the productivity which was measured by TFP, ratio of concentration, and industry sale level, as well as the control variable for the aggregate of macro economy, which were BI Rate such as what had been used in the empirical study on the influence of exchange rate toward the performance of the manufacturing industry in Indonesia (Surjaningsih, N., dkk, 2011). In that research, it was concluded that the appreciation of the real exchange rate did not prove to give pressure toward the performance of the industry sector in Indonesia empirically. However, along the inclined of the content of export industry, the appreciation of the real exchange rate would give pressure toward the performance of the manufacturing industry in Indonesia. Thus, it was indicated that there was a threshold of the real exchange rate which influence negatively toward the performance of the manufacturing industry in Indonesia.

Variable indicated to be influenced by the real excahnge rate is the degree of industry sale that on its turn, it will give impact toward the level of company profit. If the real exchange rate starts to give pressure toward the manufacturing sector, then, the level of sale of the industry (measured by the growth) will return to be negative and will decrease the level of the 
manufacturing industry. Therefore, the variable which interacts with the threshold of the real exchange rate is the SALES with the basic model as follow:

$$
\begin{gathered}
\text { Profit }_{i t}=\mu_{i}+\theta_{1} \text { BIRate }_{i t}+\theta_{2} \text { TFP }_{i t}+\theta_{3} \text { CR }_{i t} \\
+\beta_{1} \text { Sales }_{i t} \mathrm{I}\left(E R_{i t} \leq \gamma\right)+\beta_{2} \text { Sales }_{i t} \mathrm{I}\left(E R_{i t}>\gamma\right)+e_{i t}
\end{gathered}
$$

This research on the threshold of the real exchange rate in manufacturing industry in Indonesia is conducted in the level of the individual of the company. The threshold of the real exchange rate above is either in the form of level or growth in order to get the sensitivity of the manufacturing industry in Indonesia toward the level of the real exchange rate occurred.The samples used were the individual of company listed in the survey of big-and-medium-scaledindustry published by BPS period 2001-2009. Knowing that the threshold method is design for the data of balanced panel, thus, in this research, there are 225 companies chosen in that period of time as the samples of the research (the Table of Sample Distribution).

\begin{tabular}{c|l|c|c}
\multicolumn{3}{c}{ Sample Distribution } \\
KKI2 & \multicolumn{1}{|c}{ Industry Group Name } & Company Number & $\%$ \\
15 & Food and beverage & 84 & 37.33 \\
\hline 16 & Tobacco & 9 & 4.00 \\
\hline 17 & Textile & 11 & 4.89 \\
\hline 18 & Apparel & 1 & 0.44 \\
\hline 19 & Goods from leather & 6 & 2.67 \\
\hline 20 & Goods from wood and woven & 10 & 4.44 \\
\hline 21 & Goods from paper & 5 & 2.22 \\
\hline 22 & Publishing, printing and reproduction & 11 & 4.89 \\
\hline 24 & Goods from chemical material & 12 & 5.33 \\
\hline 25 & Rubber and goods from plastic & 26 & 11.56 \\
\hline 26 & Non metal extractive & 21 & 9.33 \\
\hline 28 & Goods from metal and its tools & 4 & 1.78 \\
\hline 31 & Other electric machinery and its equipment & 1 & 0.44 \\
\hline 36 & Furniture and other processing industries & 24 & 10.67 \\
\hline & & 225 & 100.00 \\
& & &
\end{tabular}

In this research, the company performance is measured by using profitability or profit level which is that company ability to get profit that is measured relatively toward fixed asset total that can be seen as follows:

$$
\text { Profitabilitas }_{i t}=\frac{\text { output }_{\text {it- }} \text { input }_{\text {it }}}{\text { total aset }_{i t}}
$$


Meanwhile, verify variable used and expectation sign wanted from the econometric test result can be seen in following table:

\begin{tabular}{|c|c|c|c|}
\hline \multicolumn{4}{|c|}{$\begin{array}{c}\text { Table } 2 \\
\text { Variable Used and Sign Expectation }\end{array}$} \\
\hline Variable & Definition & Data Type & $\begin{array}{c}\text { Sign } \\
\text { Expectation }\end{array}$ \\
\hline $\begin{array}{l}\text { TFP } \\
\text { (Total Factor } \\
\text { Productivity) } \\
\text { or Tecnology Level }\end{array}$ & $\begin{array}{l}\text { Productivity of industry sector, calculated by using } \\
\text { Solow Residual model and Cobb Douglas function } \\
\qquad \begin{array}{l}Y=A K^{\alpha} L^{\beta} \\
\text { In } Y=\ln A+\alpha \ln K+\beta \ln L\end{array}\end{array}$ & $\begin{array}{l}\text { annual, BPS, } \\
\text { 2001-2009 }\end{array}$ & + \\
\hline $\begin{array}{l}\text { CR } \\
\text { (Concentration } \\
\text { Ratio) }\end{array}$ & $\begin{array}{l}\text { The measurement of market concentration level that } \\
\text { represents the market competition level, with range } \\
\text { from } 0 \text { (perfect competition market) to } 1 \text { (monopoly } \\
\text { market) } \\
\qquad \text { CR }= \\
\frac{\text { (output from } 4 \text { biggest company in sub sector industry) }}{\text { (total output in certain sub sector industry) }}\end{array}$ & $\begin{array}{l}\text { annual, BPS, } \\
\text { 2001-2009 }\end{array}$ & $\begin{array}{l}\text { - or }+ \\
\text { (rely on the } \\
\text { valid } \\
\text { profitability } \\
\text { theory) }\end{array}$ \\
\hline SALES & $\begin{array}{l}\text { Sales growth in industry sector is as the potency proxy } \\
\text { of industry sector development in the future, by } \\
\text { separating the number of sales of expected individual } \\
\text { company. } \\
\qquad \begin{array}{c}\text { Sales growth }= \\
\frac{\text { Total sales(t)-Total sales(t-1) }}{\text { Total sales(t-1) }} \times 100 \%\end{array}\end{array}$ & $\begin{array}{l}\text { annual, BPS, } \\
2001-2009\end{array}$ & + \\
\hline $\begin{array}{l}\text { REER (Real } \\
\text { Effective } \\
\text { Exchange Rate) }\end{array}$ & $\begin{array}{l}\text { The exchange rate index of Rupiah per money currency } \\
\text { countries of main trade partner which is weighted by } \\
\text { total export and import from the main trade partner } \\
\text { (AS, EU and Japan). } \\
\text { REER variable used either in the form of level or growth. } \\
\text { REER calculation are as follow: } \\
\text { (i) Calculate the value of Nominal Effective Exchange } \\
\text { Rate (NEER) } \\
\text { a.Conducting relatively exchange value index } \\
\text { between rupiah and other main trade partner } \\
\text { currency money toward USD with } 2007 \text { as a base } \\
\text { year. }{ }^{5} \\
\qquad \frac{e}{e^{*}}=\frac{\text { USD }}{\mathrm{e}^{*}} \rightarrow \frac{1}{\text { USD }}=\frac{\mathrm{e}^{*}}{\mathrm{U}^{*}} \\
\qquad \mathrm{USD}^{\mathrm{U}} \\
\text { USD } \\
\text { b. The relative exchange value index in every } \\
\text { country of main trade partner that have been } \\
\text { indexed then it will be weighted with the trade } \\
\text { market in related country. } \\
\text { The value of relative exchange rate country } \\
\left.\text { i (e }{ }_{i}^{*}\right)^{\alpha_{i}} \\
\text { c. Calculating NEER value which is gathered from } \\
\text { the multiplying result of relative exchange value } \\
\text { that has been weighted in among country of } \\
\text { main trade partner for each commodity. } \\
\text { NEER }\end{array}$ & $\begin{array}{l}\text { annual, BI, } \\
2001-2009\end{array}$ & $\begin{array}{c}+ \\
\text { (below } \\
\text { threshold) } \\
\text { and } \\
- \\
\text { (above } \\
\text { threshold) }\end{array}$ \\
\hline
\end{tabular}

5 Pemilihan tahun 2007 tersebut dengan alasan kondisi perekonomian Indonesia cukup kondusif untuk melakukan perdagangan internasional. 


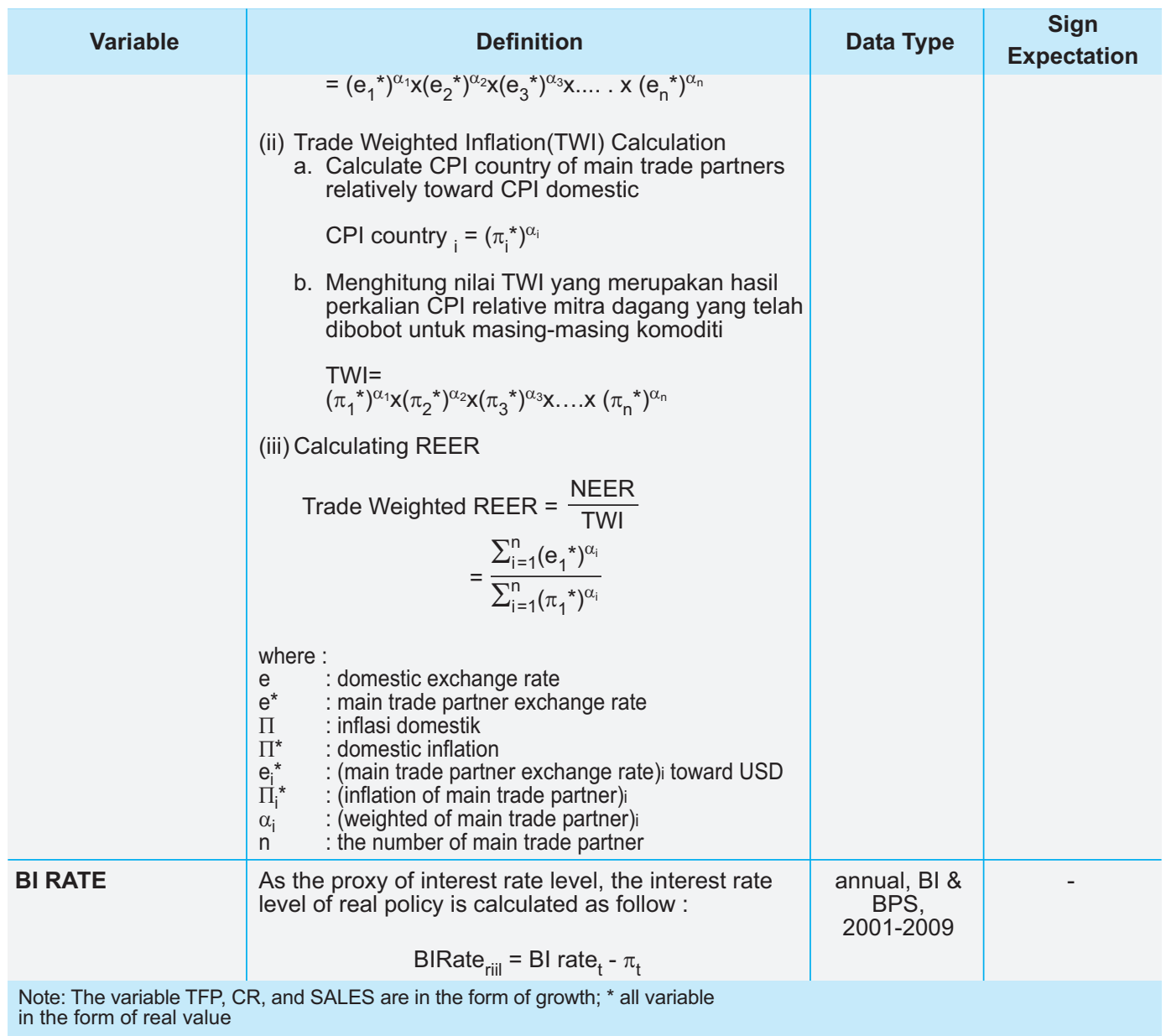

Economic of scale become an important factor for company in monopolistic competition market because it will determine the company profit level. Company with a higher technology level will produce an efficient product and give a higher profit level. Control variable which are CR and SALES represents the future prospect in industry sector, where company will have a higher profit level if operated in more condusive market. If the relation between profit and CR is negative, then company will have a better profit level if this company is located inside market that is dominated by 4 big companies (CR which is higher). However, if the the relation between profit and CR is positive, it indicates that the theory of SCP was implemented inside the industry. An efficient company will capable to sale its product cheaper than its competitor product so that its company market share increase. The increasing of this market share will increase the concentration ratio in industry. Moreover, company will have a better profit level if its market potency is bigger (SALES which is higher). Associated with the influence of real exchange rate toward company profit level that is doing export, the appreciation of exchange rate will give a benefit for companies in overseas because these companies can sell goods in a cheaper price in 
domestic currency money. Therefore domestic company is forced in a high competition either in domestic market or export. In order to maintain its competitiveness, domestic company must do some adjustments and one of these adjustments is by reducing marginal profit so that the company profit level is decline. Meanwhile, BI RATE is a control variable from the side of macro economic which is as measurement approach of external cost to increase the industry sector capacity in order to have a higher economic of scale.

\section{RESULT AND ANALYSIS}

This research on the threshold of the real exchange rate will focus on the identification of the threshold of the value if the real Rupiah exchange rate in the manufacturing industry in Indonesia both in the form of level of the real exchange rate and the change of the value of exchange rate. As what have been explained, this research used the threshold regression model developed by Hansen using the assumption of panel data of fixed panel. Thus, there was caveat in this research because all models used for KKI 2 were panel data of fixed panel. The basic regression model used is below, with variation of lag addition on its independent variables:

$$
\text { Profit }_{i t}=C+\alpha_{1} \text { BIRate }_{i t}+\alpha_{2} \text { TFP }_{i t}+\alpha_{3} C R_{t}+\alpha_{4} \text { Sales }_{i t}+\alpha_{5} E R_{t}+e_{i t}
$$

With the model of threshold regression is:

$$
\begin{gathered}
\text { Profit }_{i t}=\mu_{i}+\theta_{1} \text { BIRate }_{i t}+\theta_{2} \text { TFP }_{i t}+\theta_{3} \text { CR }_{i t} \\
+\beta_{1} \text { Sales }_{i t} \mathrm{I}\left(E R_{i t} \leq \gamma\right)+\beta_{2} \text { Sales }_{i t} \mathrm{I}\left(E R_{i t}>\gamma\right)+e_{i t}
\end{gathered}
$$

To find out the candidate of the threshold of the real exchange rate in the manufacturing industry sector, it used 400 quantiles which was the threshold was searched in certain quantile $\{1,00 \% ; 1,25 \% ; 1,50 \% ; 1,75 \% ; \ldots ; 98,50 \% ; 98,75 \% ; 99,00 \%\}$ along the range level of the real exchange rate on the research period $(81,49 ; 101,13)$ and the changed of the exchange rate $(-5,71 ; 20,09)$. For the test of robustness, a bootsrap was reconducted for about 1000 times.

Meanwhile, the regression model separated the exporter company by sorting the companies which answered consistently that they export their output on the questioner of SIBS. For this needs, there had been 16 companies sorted out.

The estimation of threshold for the total of the industry was conducted both by level of REER and the growth of REER. To find out the threshold, it was based on the model developed byBaggs (2011), regression also used the lag of independent variable.

The estimation of equation both in level and the growth of REER could be seen on table of the Result of the Regression of the Fixed Effect Level REER below. The variable of TFP was positive and significant on influencing the profit level almost in all equation except for the profit 
using the variable of TFP lag (1). It meant that, the higher technology level would increase the profit level of a company. Thus, the effort to boost the performance of the manufacturing industry sector in a total way could be conducted by using the more advanced technology.

While, the positive and siginificant of REER impact toward both on the equation with level of REER and the growth of REER. This findings meant that the level of the real exchange rate $(81,49 ; 101,13)$ and the growth of the exchange rate $(-5,71 \% ; 20,09 \%)$ yoy had yet to give pressure toward the performance of the manufacturing industry sector in Indonesia. This result confirmed the previous research which was conducted on the level of sub-sector of industry by using unbalanced panel data. ${ }^{6}$ Whereas, the variables of BI Rate, CR, and Sales were insignificant for all equation. This insignificancy of the variable of CR meant that the theory of SCP did not applicable for the manufacturing industry sector in Indonesia. In contrast, the significant of TFP strengthtened the theory of Firm Effect Model which stated that the different characteristics in the level of company cause the different in the profitability level. The important of TFP in forming the profitability of company supported the survival of the company which became the samples of the research. Meanwhile, the variable of Sales as the proxy of the market potency was insignificant, this might be because of the structure of the market which tended to be elastic market ${ }^{7}$ and low profit level.

Furthermore, the regression which separated 2 regimes based on the threshold of the exchange rate according to the equation 3.18, it found that there was threshold of the exchange rate on the value level of REER 82,24 and significant on $\alpha=5 \%$. The level of the real exchange rate above 82,24 until 101,13 was the interval of secure exchange rate for the performance of manufacturing sector. On the other side, the threshold of the growth of the real exchange rate was $-5,01 \%$ (yoy) and significant on $\alpha=3 \%$. The growth of the exchange rate above $-5.01 \%$ (yoy) until 20,09\% (yoy) was the secure growth of the exchange rate for the manufacturing industry in Indonesia. The value of the threshold either by level or by its growth was a consistent threshold value because it was located on the Confidence Interval.

6 Surjaningsih et al, "Rigiditas Penawaran : Faktor-faktor Penyebab Melemahnya Kinerja Sektor Industri", Bank Indonesia, 2011.

7 Rata-rata CR sebesar 0,28 


\begin{tabular}{|c|c|c|c|c|c|c|}
\hline \multicolumn{7}{|c|}{$\begin{array}{c}\text { Table } 3 \\
\text { The Result of Fixed Effect Regression of REER Level of Total Industry }\end{array}$} \\
\hline \multirow[b]{2}{*}{ Variabel } & \multicolumn{2}{|l|}{ (1) } & \multicolumn{2}{|c|}{ (2) } & \multicolumn{2}{|l|}{ (3) } \\
\hline & Panel FE & $\underset{\text { Error }}{\text { Standard }}$ & Panel FE & $\underset{\text { Error }}{\text { Standard }}$ & Panel FE & $\underset{\text { Error }}{\text { Standard }}$ \\
\hline Konstanta & -3.212 * & 1.935 & 0.033 & 0.028 & -2.238 & 2.738 \\
\hline BIRate & -0.054 & 0.088 & & & & \\
\hline BIRate $_{(-1)}$ & & & -0.174 & 0.119 & -0.145 & 0.118 \\
\hline TFP & $0.397^{* * *}$ & 0.112 & & & $0.355^{* * *}$ & 0.115 \\
\hline $\operatorname{TFP}_{(-1)}$ & & & 0.106 & 0.122 & & \\
\hline $\mathrm{CR}$ & 0.001 & 0.003 & & & & \\
\hline $\mathrm{CR}_{(-1)}$ & & & 0.000 & 0.003 & 0.000 & 0.003 \\
\hline Sales & 0.004 & 0.005 & & & & \\
\hline Sales $_{(-1)}$ & & & 0.008 & 0.006 & 0.006 & 0.005 \\
\hline REER & 0.050 ** & 0.020 & 0.033 & 0.028 & 0.041 & 0.028 \\
\hline
\end{tabular}

\begin{tabular}{|c|c|c|c|c|c|c|c|c|c|}
\hline \multicolumn{10}{|c|}{$\begin{array}{c}\text { Table } 4 \\
\text { The Result of Threshold Regression of REER Level of Total Industry }\end{array}$} \\
\hline \multirow[b]{2}{*}{ Variabel } & \multicolumn{3}{|c|}{ (1) } & \multicolumn{3}{|c|}{ (2) } & \multicolumn{3}{|c|}{ (3) } \\
\hline & Koefisien & $\begin{array}{c}\text { Standard } \\
\text { Error }\end{array}$ & $\begin{array}{l}\text { White } \\
\text { Standard } \\
\text { Error }\end{array}$ & Koefisien & $\begin{array}{c}\text { Standard } \\
\text { Error }\end{array}$ & \begin{tabular}{|c|} 
White \\
Standard \\
Error
\end{tabular} & Koefisien & $\begin{array}{c}\text { Standard } \\
\text { Error }\end{array}$ & $\begin{array}{l}\text { White } \\
\text { Standard } \\
\text { Error }\end{array}$ \\
\hline BIRate & -0.142 & 0.085 & 0.087 & & & & & & \\
\hline BIRate $_{(-1)}$ & & & & $-0.302 * * *$ & 0.098 & 0.096 & $-0.305 * * *$ & 0.097 & 0.096 \\
\hline TFP & $0.325^{* * *}$ & 0.117 & 0.098 & & & & $0.294^{* * *}$ & 0.120 & 0.093 \\
\hline $\operatorname{TFP}_{(-1)}$ & & & & -0.037 & 0.143 & 0.085 & & & \\
\hline CR & 0.000 & 0.003 & 0.002 & & & & & & \\
\hline $\mathrm{CR}_{(-1)}$ & & & & 0.000 & 0.004 & 0.003 & -0.000 & 0.004 & 0.003 \\
\hline Sales (REER $<=82,24)$ & -0.008 & 0.010 & 0.005 & & & & & & \\
\hline Sales (REER $>82,24)$ & 0.004 & 0.006 & 0.009 & & & & & & \\
\hline Sales $_{(-1)}(\operatorname{REER}<=82,24)$ & -0.008 & 0.010 & 0.005 & -0.080 & 0.045 & 0.051 & -0.083 & 0.045 & 0.051 \\
\hline Sales $_{(-1)}(\operatorname{REER}>82,24)$ & 0.004 & 0.006 & 0.009 & 0.007 * & 0.005 & 0.004 & $0.006 *$ & 0.005 & 0.004 \\
\hline Test Efek Threshold & \multicolumn{3}{|c|}{ (1) } & \multicolumn{3}{|c|}{ (2) } & \multicolumn{3}{|c|}{ (3) } \\
\hline Threshold & \multicolumn{3}{|c|}{82.24} & \multicolumn{3}{|c|}{82.24} & \multicolumn{3}{|c|}{82.24} \\
\hline Confidence Interval & \multicolumn{3}{|c|}{$[81.49,101.13]$} & \multicolumn{3}{|c|}{$[81.49,101.13]$} & \multicolumn{3}{|c|}{$[81.49,101.13]$} \\
\hline $\mathrm{F}$ & \multicolumn{3}{|c|}{0.88} & \multicolumn{3}{|c|}{2.37} & \multicolumn{3}{|c|}{3.15} \\
\hline p-value & \multicolumn{3}{|c|}{0.42} & \multicolumn{3}{|c|}{0.03} & \multicolumn{3}{|c|}{0.03} \\
\hline$(10 \%, 5 \%, 1 \%)$ & \multicolumn{3}{|c|}{$(3.01,4.09,6.49)$} & \multicolumn{3}{|c|}{$(1.22,2.01,4.18)$} & \multicolumn{3}{|c|}{$(1.75,2.58,4.19)$} \\
\hline
\end{tabular}


Table 5

The Result of Fixed Effect Regression of REER Growth of Total Industry

(1)

\begin{tabular}{|c|c|c|c|c|c|c|}
\hline & \multicolumn{2}{|l|}{ (1) } & \multicolumn{2}{|c|}{ (स) } & \multicolumn{2}{|c|}{ (3) } \\
\hline Variabel & Panel FE & $\begin{array}{c}\text { Standard } \\
\text { Error }\end{array}$ & Panel FE & $\begin{array}{c}\text { Standard } \\
\text { Error }\end{array}$ & Panel FE & $\begin{array}{c}\text { Standard } \\
\text { Error }\end{array}$ \\
\hline Konstanta & $1.443^{* * *}$ & 0.374 & $2.347^{* * *}$ & 0.403 & $1.646^{* * *}$ & 0.381 \\
\hline BIRate & -0.129 & 0.084 & & 0.092 & & \\
\hline BIRate $_{(-1)}$ & & & $-0.223^{* *}$ & 0.092 & $-0.223^{* *}$ & 0.091 \\
\hline TFP & $0.343^{* * *}$ & 0.112 & & & $0.323^{* * *}$ & 0.115 \\
\hline $\operatorname{TFP}_{(-1)}$ & & & 0.078 & 0.123 & & \\
\hline CR & 0.000 & 0.003 & & & & \\
\hline $\mathrm{CR}_{(-1)}$ & & & -0.000 & 0.003 & -0.001 & 0.003 \\
\hline Sales & 0.003 & 0.005 & & & & \\
\hline Sales $_{(-1)}$ & & & 0.006 & 0.005 & 0.004 & 0.005 \\
\hline REERg & 0.028 * & 0.015 & 0.032 * & 0.019 & 0.028 & 0.019 \\
\hline
\end{tabular}

Table 6

The Result of Threshold Regression of REER Growth of Total Industry

\begin{tabular}{|c|c|c|c|c|c|c|c|c|c|}
\hline & \multicolumn{3}{|c|}{ (1) } & \multicolumn{3}{|c|}{ (2) } & \multicolumn{3}{|c|}{ (3) } \\
\hline Variabel & Koefisien & $\begin{array}{c}\text { Standard } \\
\text { Error }\end{array}$ & $\begin{array}{c}\text { White } \\
\text { Standard } \\
\text { Error }\end{array}$ & Koefisien & $\begin{array}{c}\text { Standard } \\
\text { Error }\end{array}$ & $\begin{array}{c}\text { White } \\
\text { Standard } \\
\text { Error }\end{array}$ & Koefisien & $\begin{array}{c}\text { Standard } \\
\text { Error }\end{array}$ & $\begin{array}{c}\text { White } \\
\text { Standard } \\
\text { Error }\end{array}$ \\
\hline BIRate & $-0.175^{*}$ & 0.087 & 0.096 & & & & & & \\
\hline BIRate $_{(-1)}$ & & & & $-0.302 * \star \star *$ & 0.098 & 0.095 & $-0.305^{* * \star}$ & 0.097 & 0.096 \\
\hline TFP & $0.300^{* * *}$ & 0.117 & 0.093 & & & & $0.294 * * *$ & 0.120 & 0.093 \\
\hline $\operatorname{TFP}_{(-1)}$ & & & & -0.004 & 0.143 & 0.085 & & & \\
\hline $\mathrm{CR}$ & 0.000 & 0.003 & 0.002 & & & & & & \\
\hline $\mathrm{CR}_{(-1)}$ & & & & 0.000 & 0.004 & 0.003 & -0.000 & 0.004 & 0.003 \\
\hline Sales (REERg $<=19,64$ ) & -0.011 ** & 0.008 & 0.005 & & & & & & \\
\hline Sales (REERg $>19,64)$ & 0.011 & 0.007 & 0.012 & & & & & & \\
\hline Sales $_{(-1)}\left(\right.$ REERg $\left._{<}<=-5,01\right)$ & & & & -0.080 & 0.045 & 0.051 & -0.083 & 0.045 & 0.051 \\
\hline Sales$_{(-1)}($ REERg $>-5,01)$ & & & & $0.007 *$ & 0.005 & 0.004 & $0.006 *$ & 0.005 & 0.0035 \\
\hline Test Efek Threshold & \multicolumn{3}{|c|}{ (1) } & \multicolumn{3}{|c|}{ (2) } & \multicolumn{3}{|c|}{ (3) } \\
\hline Threshold & \multicolumn{3}{|c|}{19.64} & \multicolumn{3}{|c|}{-5.01} & \multicolumn{3}{|c|}{-5.01} \\
\hline Confidence Interval & \multicolumn{3}{|c|}{$[-5.71,20.09]$} & \multicolumn{3}{|c|}{$[-5.71,20.09]$} & \multicolumn{3}{|c|}{$[-5.71,20.09]$} \\
\hline $\mathrm{F}$ & \multicolumn{3}{|c|}{2.08} & \multicolumn{3}{|c|}{2.37} & \multicolumn{3}{|c|}{3.15} \\
\hline $\mathrm{p}$-value & \multicolumn{3}{|c|}{0.17} & \multicolumn{3}{|c|}{0.06} & \multicolumn{3}{|c|}{0.05} \\
\hline$(10 \%, 5 \%, 1 \%)$ & \multicolumn{3}{|c|}{$(2.86,3.90,5.21)$} & \multicolumn{3}{|c|}{$(1.73,2.50,3.99)$} & \multicolumn{3}{|c|}{$(2.08,3.01,5.18)$} \\
\hline
\end{tabular}

Translation note: koefisien $=$ coefficient, variabel $=$ variable, test efek threshold $=$ threshold effect test 
The sector of manufacture industry was more sensitive to depreciation than appreciation where the industry structure was still using import component. This statement was confirmed by survey that was taken by Bank Indonesia which was almost 40\% respondents that was come from manufacture sector was worried about the sharply depreciation of Rupiah and the portion of manufacture company using import raw material was quite big which was $35,2 \%$ of total manufacture industry. The weakening of real exchange rate would increase the production cost because the import raw material was more expensive so that the company profit level would be smaller.

\section{CONCLUSION}

This paper is empirical research, and estimation result confirms the presence of threshold of the real Rupiah exchange rate on the level of 82.24. REER ranging from 82.24 to 101.13 with the growth of $-5.01 \%$ to $20.09 \%$ is secure on supporting the manufacturing company performance. This result asks the attention of monetary authority to keep the value of Rupiah within this range, which also helps to maintain the economic stability.

Future research should address some caveats on this paper; first, the use of Hansen method require balanced panel data, which lead to a selection of 225 companies during 20012009. Those samples cover only $1.1 \%$ of the total available data from Survey of Medium and Large Scale Manufacturing Industry of around twenty three thousands per year. Second, future research should leng then historical observations to cover the Asian crisis in 1997/98. This is important to capture the sharp depreciation of the Rupiah exchange rate, which may alter the threshold found on this paper. 


\section{REFERENCES}

Bodnar, Gordon M, "Exchange Rate Exposure and Industry Characteristics : Evidence from Canada, Japan, and the USA", Journal of International Money and Finance (1993), 12, 29-45

Boediono, DR., "Seri Sinopsis Pengantar Ilmu Ekonomi No.1 Ekonomi Mikro", BPFE, edisi 2, 1999.

Depari, Y., dkk, "Perilaku Pembentukan Harga Produk Manufaktur dari sisi Produsen, Distributor dan Pengecer", Bank Indonesia, 2009.

Fung, L., et.al, "Firm Survival, Performance, and the Exchange Rate ", University of Calgary, 2007.

Firdaus, Muhammad, "Ekonometrika untuk Data Panel", Materi Pelatihan di Bank Indonesia, April 2010.

Hansen, Bruce E., "Threshold Effects in Non-Dynamic Panels: Estimation, Testing, and Inference", Boston College, February 1998.

J. Baggs, E. Beaulieu, L. Fung, "Firm Survival, Performance, and the Exchange Rate", University of Calgary Discussion Paper, 2007.

J. Baggs, E., et.al., "Exchange Rate Movements and Firm Dynamics in Canadian Retail Industries", 2011.

Kurniati, Yati, dkk., "Dinamika Industri Manufaktur dan Respon terhadap Siklus Bisnis", Direktorat Riset dan Kebijakan Moneter, Bank Indonesia, 2010.

Mishra, SK, "A Brief History of Production Function" Department of Economic North-Eastern Hill University Shillong (India).

Nugroho, Wahyu Agung, dkk., "Struktur Biaya dan Perilaku Pembentukan Harga pada Industri Manufaktur Indonesia", Bank Indonesia, 2005

Pindyck, Robert S., dan Daniel L. Rubinfeld, "Microeconomics", edisi ke-4, Prentice-Hall, 1998.

Sidek, Noor Zahirah Mohd, "Malaysia : How Much Exchange Rate Misalignment is Detrimental to Export", Department of Economics, UiTM Malaysia, 2011

Simatupang, P., dkk, "Pengaruh Kenaikan Harga Bahan Bakar Minyak (BBM) Maret 2005 Terhadap Profitabilitas Usaha Jasa Alsintan dan Usaha Tani Padi (Kasus Kab. Sidrap, Sulawesi Selatan dan Kab. Nganjuk, Jawa Timur), Pusat Sosial Ekonomi dan Kebijakan Pertanian, Badan Litbang, Departemen Pertanian, 2005. 
Stierwald, A., "Determinants of Profitability: An Analysis of Large Australian Firms", Melbourne Institute Working Paper Series No.3/10, April 2010.

Surjaningsih, Ndari, dkk., "Rigiditas Penawaran : Faktor-faktor Penyebab Melemahnya Kinerja Industri", Working Paper No.10/2011, Bank Indonesia.

Wooldridge, Jeffrey M. "Introductory Econometrics A Modern Approach", South-Western Cengace Learning, 2009

Yanuarti, Tri, "Dampak Apresiasi Nilai Tukar terhadap Kinerja Industri Pengolahan", (2006), Catatan Riset, Bank Indonesia, 2006. 